\title{
O Círculo do Aventino na Roma do século IV
}

\author{
The Aventine Circle in 4th-century Rome
}

Maria Cristina da Silva Martins ${ }^{* *}$

\begin{abstract}
Resumo: Este artigo pretende divulgar o Círculo do Aventino, espécie de escola de ascetismo cristão, de estudos bíblicos e de línguas, fundado por Marcela (posteriormente Santa Marcela), na Roma do século IV e frequentado por outras damas da aristocracia romana, também santificadas. Nas reuniões desse círculo, São Jerônimo atuava como professor e conselheiro espiritual. Uma breve contextualização histórica do cristianismo do século IV, bem como a ideologia veiculada pelos Padres da Igreja sobre as mulheres, também faz parte deste artigo.
\end{abstract}

\begin{abstract}
This paper aims to spread The Aventine Circle, a kind of school of Christian asceticism, biblical and language studies, founded by Marcela (later Saint Marcella), in fourth century Rome, attended by other ladies of the Roman aristocracy, also later sanctified. In the meetings of this circle, St. Jerome acted as a teacher and spiritual advisor. A brief historical contextualization of Christianity from the IV century, as well as the ideology conveyed by the Church Fathers about women, is also part of this article.
\end{abstract}

\section{Palavras-chave:}

Círculo do Aventino. Ascetismo Feminino. Antiguidade Tardia. São Jerônimo. Cristianismo.

\section{Keywords:}

The Aventine Circle. Female asceticism. Late Antiquity.

Saint Jerome. Christianity.

\footnotetext{
* Agradeço à Michelle Raupp Selister e ao Lucas Neves Costa pela leitura atenta e revisão deste artigo. Sem dúvida, uma grande alteração no Império Romano ocorreu entre os imperadores Marco Aurélio (121-180) e Diocleciano (c. 244311), conduzindo-o ao empobrecimento, à violência e à decadência, situação que culminou com a queda do Império Romano do Ocidente, no século V. A partir daí tradicionalmente diz-se iniciar a Antiguidade Tardia, termo cunhado por RIEGL (1901), no contexto das artes (MACHADO, 2015, p. 84).

** Professora e pesquisadora de latim do Departamento de Letras Clássicas e Vernáculas da Universidade Federal do Rio Grande do Sul (UFRGS). Possui graduação em Letras Licenciatura Português-Latim pela Universidade Federal do Rio Grande do Sul, mestrado em Linguística pela Universidade Estadual de Campinas e doutorado em Linguística pela Universidade Estadual de Campinas (2002).
} 


\section{Introdução}

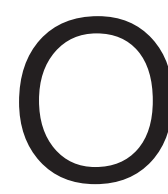

século IV foi um período de grandes transformações no Império Romano, tendo sido considerado por muitos historiadores como o período de seu declínio e de transição entre a Antiguidade Clássica e a Idade Média. As modificações sofridas no Império Romano durante esse período resultaram em grande parte da "crise do século III", provocada por dificuldades financeiras e contínuas guerras, principalmente contra germanos e hunos, que ameaçavam suas fronteiras. Embora Constantino tenha unificado o Império de 307 a 337, em 395, após a morte de Teodósio, ocorreu a sua divisão definitiva, tornando-se Roma a capital do Ocidente, e Constantinopla a do Oriente. Nesse mesmo século, o cristianismo passou de uma religião altamente perseguida, com Diocleciano, ${ }^{1}$ para a religião oficial do Império, com Teodósio I, em 380, a partir do Édito de Tessalônica. Entretanto, entre esses dois extremos, houve a conversão de Constantino e a promulgação do Édito de Milão, em 313, que instituiu a liberdade religiosa no Império, pondo fim à perseguição aos cristãos. ${ }^{2}$

Resumidamente, a trajetória intelectual e religiosa de Jerônimo ${ }^{3}$ teve início quando ele partiu de Estridão, ${ }^{4}$ na região dos Balcãs, para estudar em Roma, aos doze anos de idade, no ano de 360. Nessa altura, Jerônimo teve uma educação clássica e foi pupilo do famoso gramático Élio Donato. Conforme a prática corrente na época, foi batizado já com certa idade, aos 21 anos, em Roma, pelo papa Libério. Pouco depois de seu batismo,

\footnotetext{
${ }^{1}$ A chamada Grande Perseguição ocorreu entre 303 e 311, período no qual estiveram à frente do Império Romano Diocleciano (284-305), Maximiano (285-305; 306-308), Galério (293-311), Severo (305-306) e Maximino Daia (305313). Uma das principais fontes para compreender esse período histórico é a obra De mortibus persecutorum (c. 318), literalmente, "Sobre as mortes dos perseguidores" (traduzida para o português como "Sobre a morte dos perseguidores"), de Lactâncio (250-325), escritor cristão. Essa obra é considerada um panfleto para mostrar como todos os perseguidores, particularmente aqueles de seu próprio tempo, tiveram um fim maléfico (HAMMOND; SCULLARD, 1970, s. v. "Lactantius", p. 576). Vale lembrar que os imperadores Nero (54-68), Domiciano (81-96), Décio (249-251), Valeriano (253-260) e Aureliano (270-275) também perseguiram os cristãos.

${ }^{2}$ A partir da concessão da liberdade de culto do cristianismo, com o Édito de Milão, tiveram início as peregrinações aos Lugares Santos (MARAVAL, 2002; MARAVAL, 2004), no IV século. Nesse contexto, a narrativa de viagem conhecida como "Itinerário de Egéria" ou "Peregrinação de Egéria" destaca-se por ter sido realizada por uma mulher desacompanhada, entre 381 e 384. Cronologicamente, a Peregrinatio Egeriae é a terceira peregrinação documentada aos Lugares Santos (MARTINS, 2017).

${ }^{3}$ Juntamente com Agostinho, Ambrósio e Gregório Magno, São Jerônimo figura entre os quatro grandes doutores da Igreja do Ocidente. O duplo título de Pai da Igreja e de Doutor da Igreja foi concedido pelo papa Bonifácio VIII, por um decreto de 20 de setembro de 1295. São Jerônimo começou a ser venerado como santo quando se tornou objeto de culto público, por volta do ano 800, e incluído também no catálogo dos mártires e confessores, por volta dessa data (RICE, 1985, p. 33).

${ }^{4}$ Ele próprio descreveu o seu local de nascimento desta forma na Ep. 7, 5: In mea enim patria rusticitatis uernacula deus uenter est, et sanctior est ille, qui ditior est. "De fato, na minha pátria natal, de costumes rústicos, deus é o ventre, e é mais santo aquele que é mais rico". Há ainda outra referência à sua terra natal na biografia que escreveu sobre si mesmo em De Viris Illustribus, 135: Hieronymus patre Eusebio natus oppido Stridonis, quod a Gothis euersum. "Jerônimo, nascido de Eusébio, na cidade de Estridão, que foi varrida pelos godos".
} 
quando já havia terminado seus estudos de retórica, partiu para Trier, com seu amigo Bonósio, pois Valentiniano tinha acabado de se instalar nessa cidade com sua corte. Uma vez que era um jovem bem formado, talvez buscasse um posto na administração do Império, como desejava seu pai (MARAVAL, 1998). Isso não se concretizou, mas foi em Trier que Jerônimo decidiu-se pela vida ascética. Foi, então, para Aquileia, juntar-se ao padre Cromácio, que havia criado aí uma comunidade de clérigos e leigos em torno do ascetismo. ${ }^{5}$ Nesse local, entrou em contato com o ascetismo oriental, aprofundou-se em grego e passou a estudar hebraico. Depois desse período no deserto, dirigiu-se para Antioquia, onde se ordenou sacerdote.

A experiência ascética, o conhecimento de línguas e a notoriedade em exegese bíblica fizeram com que Jerônimo se destacasse quando voltou a Roma em 382. ${ }^{6}$ Nessa ocasião, atuou como intérprete numa delegação da Igreja, liderada pelos bispos Paulino de Antioquia e Epifânio de Salamina (CAIN, 2009, p. 44). ${ }^{7}$

O conjunto de competências de Jerônimo fez com que o papa Dâmaso o contratasse como secretário. De fato, de 382 a 385, trabalhou nos escritórios do papa, onde respondia às consultas sinodais do Oriente e do Ocidente (Ep. 123, 9). ${ }^{8}$ Logo que o papa Dâmaso percebeu a perfeição de seu estilo em latim e o seu profundo domínio de grego, de hebraico e das Escrituras, encarregou-o de uma reformulação da tradução da Bíblia, o que culminou numa nova tradução a partir do hebraico para o latim. ${ }^{9}$ Além disso, indicou-o a participar de reuniões com um grupo de mulheres de família senatorial, que se encontravam para estudar as Escrituras, entre outras práticas cristãs. Jerônimo assumiu

\footnotetext{
${ }^{5}$ A cronologia da vida de São Jerônimo, do seu nascimento à sua chegada em Roma em 382, permanece bastante imprecisa, por falta de dados datáveis nos textos. A cronologia de Callavera (Saint Jérôme: sa vie et son œuvre, 1922, apud MARAVAL, 1998, p. 15, n. 2) é a mais correntemente adotada e data a partida para o Oriente em 374 . Maraval (1998) pensa que essa data é tardia demais, e propõe 371 ou 372.

${ }^{6}$ Entre 374 e 380, Jerônimo viajou por vários lugares do Oriente, como Antioquia, Aquileia e Constantinopla. Na verdade, além de ter sido teólogo, filólogo, tradutor, exegeta, e de ter desenvolvido uma enorme obra literária, Jerônimo foi um grande viajante. Desde que saiu de sua cidade natal para estudar em Roma, viveu em diversos lugares - Roma, Trier, Aquileia, Antioquia, Constantinopla e Belém -, e também passou por muitos outros em viagem, sendo os mais importantes os territórios da Cilícia, Capadócia, Egito, Grécia e a ilha de Chipre. Para um estudo aprofundado sobre as viagens de São Jerônimo, sua vida e carreira, vide Bernard (1864).

${ }^{7}$ Poucos autores abordam a questão de onde teriam se hospedado os bispos Epifânio e Paulino, e Jerônimo, quando chegaram a Roma, em 382. Maraval (1998), Henne (2009) e Moreno (1992) afirmam que o bispo Epifânio foi acolhido na casa de Paula, mas restam muitas dúvidas sobre o benfeitor ou a benfeitora que teria recebido Jerônimo. Apenas Maraval (1998) sustenta que Jerônimo foi hospedado na casa de Marcela. Seja como for, é unânime a afirmação, na bibliografia consultada, que o papa introduziu Jerônimo ao círculo de mulheres que se reunia na casa de Marcela, com o objetivo de estudar a Bíblia.

${ }^{8}$ Ep. 123,9: Ante annos plurimos, cum in chartis Ecclesiasticis iuuarem Damasum Romanae urbis Episcopum, et Orientis atque Occidentis synodicis consultationibus responderem [...]. "Durante muitos anos, como respondesse às cartas eclesiásticas em consultas de sínodos do Oriente e do Ocidente para ajudar Dâmaso, pontífice da cidade romana [...]". ${ }^{9}$ A tradução da Bíblia a partir do hebraico, realizada entre 390 e 405, denominada Vulgata, é a obra mais importante de sua vida. Entretanto, concordamos com Arns (2007, p. 89), quando declara que são as cartas de São Jerônimo a parte mais pessoal e mais reveladora de sua obra literária.
} 
a posição de instrutor, mestre, conselheiro espiritual e propagandista da vida ascética para essas nobres damas, também no período de 382 a 385. Esse local de encontro de mulheres aristocráticas ficou conhecido como "Círculo do Aventino", pois tinha lugar na casa de Marcela, situada no Monte Aventino. De um modo essencialmente descritivo, o relacionamento entre Jerônimo e essas nobres damas romanas no Círculo do Aventino será o objeto deste artigo. As possíveis inserções e contribuições do Círculo do Aventino à historiografia, bem como a análise mais profunda do ponto de vista ideológico da obra epistolográfica de São Jerônimo não serão abordadas. No entanto, algumas implicações ideológicas do cristianismo em relação às mulheres, destacadas por Clark (1983; 1994; 1999), e igualmente das epístolas de São Jerônimo, ressaltadas por Cain (2006; 2009), norteiam nosso trabalho. Finalmente, convém notificar que todas as traduções do latim foram realizadas por nós, sendo, portanto, de nossa inteira responsabilidade.

\section{O ascetismo no cristianismo}

No final do século IV, o movimento ascético dentro do cristianismo havia conquistado muitos adeptos. Rufino de Aquileia e Paládio informaram que, por volta do ano de 370, três mil monges viviam no mosteiro de Nítria, no Egito, e que, em 390, esse número teria sido em torno de cinco mil (CLARK, 1999, p. 34).

No Ocidente, São Jerônimo foi um encorajador do ascetismo, tendo ele próprio vivido como monge asceta no deserto da Síria, entre 375 e 377. As primeiras de suas dezesseis epístolas (Ep. 2-17) têm sido consideradas como fontes documentais dos primeiros estágios de sua carreira monástica e literária (CAIN, 2006; MARAVAL, 1998; KELLY, 1975). ${ }^{10}$ Porém, a descrição do período em que viveu no deserto está fora desse conjunto de cartas, encontrando-se relatada, na carta 22, dedicada à Eustóquia. A intenção da carta é de aconselhar Eustóquia, filha de Paula, a preservar a virgindade, considerada a primeira etapa do ascetismo cristão. Para muitos Padres da Igreja, a abstinência sexual era o começo de uma vida de asceta, que também incluía períodos de jejum, redução do sono, desapego de bens materiais, além do fortalecimento de virtudes morais, como a superação da raiva e do orgulho.

A Epístola 22 é, de fato, um enorme livreto (libellus), podendo ser considerado um panfleto de propaganda dos benefícios da vida ascética para as mulheres. Destacamos

\footnotetext{
${ }^{10}$ Sobre a vida no deserto destaca-se a Epístola 14 de estilo retórico, na qual Jerônimo, com muito entusiasmo, convida Heliodoro a juntar-se a ele para adotar o ascetismo. Esse contentamento não dura muito, porque na carta 17, escrita no fim desse período em que viveu no deserto da Síria, Jerônimo confessa haver muitos problemas entre ele e os monges locais, devido ao cisma entre a Igreja Ocidental e a Oriental, vigente na época: "uma coisa agradaria (a eles): que eu vá embora daqui. Logo, logo, cedo" (Ep. 17, 3: Unum tantum placet hinc recedam. Iam iam cedo).
} 
abaixo um pequeno trecho dessa carta, em que Jerônimo, embrenhado no deserto de Cálcis, relata:

\begin{abstract}
O quotiens in heremo constitutus et in uasta solitudine, quae exusta solis ardoribus horridum monachis praestat habitaculum, putaui me Romanis interesse deliciis! Sedebam solus, quia amaritudine repletus eram. Horrebam sacco membra deformis, squalida citus situm Aethiopicae carnis adduxerat. Cotidie lacrimae, cotidie gemitus et, si quando repugnantem somnus inminens oppressisset, nuda humo uix ossa haerentia conlidebam. De cibo uero et potu taceo, cum etiam languentes aqua frigida utantur et coctum aliquid accepisse luxuriae sit. Ille igitur ego, qui ob gehennae metum tali me carcere ipse damnaueram, scorpionum tantum socius et ferarum, saepe choris intereram puellarum. Pallebant ora ieiuniis et mens desideriis aestuabat in frigido corpore, et ante hominem suum iam carne praemortua sola libidinum incendia bulliebant.
\end{abstract}

Ó, quantas vezes eu, instalado no deserto e naquela vasta solidão, abrasada pelo sol ardente, horrível morada oferecida aos monges, imaginei-me estando presente aos prazeres romanos! Sentava sozinho, pois havia sido consumido pelo amargor. Eu, deformado, erguia meus membros como um saco; minha pele esquálida havia sido aproximada à de um etíope. Passava os dias em lágrimas e em gemidos, e, quando o sono iminente tivesse me vencido, mesmo eu sendo resistente, deixava cair dolorosamente meus ossos imóveis no chão nu. Sobre a comida e a bebida, calo-me, como também sobre os enfermos que faziam uso de água fria e sobre qualquer comida quente que seria um luxo. Portanto, aquele eu, por medo da Geena, tinha ele próprio me condenado a tal cárcere, e companheiro de tantos escorpiões e feras, muitas vezes sentia-me presente às danças das jovens moças. As bocas empalideciam pelo jejum e, no corpo frio, a mente aquecia pelos desejos. Diante desse homem, com o corpo já prematuramente morto, só ferviam os incêndios dos desejos (Ep., 22, 7, tradução nossa).

Inicialmente, o modo de vida ascético era essencialmente masculino, mas temos testemunho de comunidades ascéticas femininas instaladas no Egito, no início do século IV (CLARK, 1983, p. 133). Essas comunidades femininas cresceram seguindo o modelo do monge egípcio Pacômio, ${ }^{11}$ que criou a prática do monaquismo comunitário, afastandose do ascetismo solitário do deserto. O ascetismo, teoricamente, é um meio pelo qual se atinge a humildade e, com isso, o reino de Deus. Vários autores entre a bibliografia consultada afirmam que a prática do ascetismo no século IV substituiu a morte pelo martírio, como forma de manifestar o compromisso cristão.

Sob forte influência dessa vida monástica do Oriente, houve a formação de dois grupos comunitários femininos em torno do ascetismo, na Roma do século IV, liderados por Paula e Marcela. Inicialmente, tanto Paula quanto Marcela desejavam compreender a fundo as Escrituras, o que significava aprender grego, hebraico e exegese bíblica. Buscavam renunciar ao luxo e viver uma vida de oração e caridade, depois de terem se tornado viúvas. Um segundo casamento era totalmente desaconselhado pelos Padres

\footnotetext{
${ }^{11}$ Sabemos sobre Pacômio por intermédio de Paládio, escritor do século V, em seu livro História Lausíaca (BUTLER, 2014).
} 
da Igreja, ${ }^{12}$ como Tertuliano, João Crisóstomo e, inclusive, Jerônimo. Este, na Ep., 123, 8 (ad Geruchiam), dirigindo-se a uma nobre viúva gaulesa, emite-lhe a opinião de que um segundo casamento não lhe faria deixar de ser cristã, mas que a deixaria impura. Para sustentar essa argumentação, faz um paralelo com a Arca de Noé, que abrigava animais puros e impuros.

O juízo de valor em relação ao gênero feminino, tanto das Escrituras quanto da sociedade antiga, era de menosprezo, desconsideração e desprestígio. As mulheres eram vistas como inferiores, tanto física quanto intelectualmente. Por um lado, representavam Eva e todo o pecado perpetuado por essa herança; por outro, eram virtuosas quando obedientes aos pais e aos maridos. De acordo com Marcos Sanchez (1986, p. 243), a caracterização da mulher, seja por suas qualidades valorosas - dedicação ao lar, respeito ao marido e às leis de Deus -, seja por sua desqualificação como a expressão do mal, repousa igualmente numa atitude misógina, eliminando-a de qualquer possibilidade de equiparação ao homem. Dessa forma, o modo de vida ascético possibilitava às mulheres uma real mudança de estatuto social, ${ }^{13}$ pois as conduzia ao caminho da perfeição (Virgem Maria) e, novamente, à conquista da pureza do paraíso perdido, além de lhes permitir sair do jugo do marido e do casamento.

Entretanto, adotar o ascetismo não estava ao alcance de muitas mulheres. Sabemos que, no mundo antigo, o acesso à educação se dava a uma parcela muito pequena da população, normalmente da classe alta e do gênero masculino. Por essa razão, tanto no Círculo do Aventino, como em outras participações femininas da Antiguidade, podemos considerar como afortunadas e, em certa medida, "transgressoras" as mulheres que conseguiram deixar algum legado para a posteridade. ${ }^{14}$ Mesmo que o estereótipo da mulher fosse o de um ser com fraqueza física e intelectual, inconstância emocional e capaz de maldades intencionais para com o homem, encontram-se, na literatura patrística, referências à doçura de sua alma, à sua bondade, inteligência e sensibilidade. Para Constantino, o Grande, e Santo Agostinho, Santa Helena e Santa Mônica, respectivamente

\footnotetext{
${ }^{12}$ Clark (1994) mostra que os Padres da Igreja sustentavam a naturalização da fraqueza e da incapacidade da mulher para legitimar a sua submissão ao pai e ao marido. Narrativas bíblicas, citações da literatura clássica e dos mitos de Roma eram trazidas com esse propósito. Segundo a autora, os Padres da Igreja ajudaram a promover essa relação de poder assimétrica entre homens e mulheres, que acabou prevalecendo através dos séculos. No Novo Testamento, especialmente nas Epístolas de Paulo de Tarso, lê-se sobre a superioridade do macho, e sobre a natural submissão da mulher ao homem, o que não acontece no Gênesis.

${ }^{13}$ Novamente Clark (1994) trata em profundidade da questão da ideologia de gênero na Antiguidade, analisando as marcas ideológicas dos Padres da Igreja, sob a luz dos conceitos políticos de Althusser, Marx, Gramsci, entre outros. A ideologia de gênero pode ser vista, sem dúvida, como uma estratégia de contenção do feminino e de negação de sua participação na sociedade. A fraqueza física e mental das mulheres era tomada como um padrão universal e natural das mulheres, que servia de base para a sua segregação e contenção.

${ }^{14}$ Veja-se Melânia, a Velha (340-410), Melânia, a Jovem (383-439), Pelágia (430-457), Tecla (séc. I d.C.), Olímpia (361-408)

e Egéria (séc. IV), restringindo-nos à Antiguidade Tardia.
} 
suas mães, eram exemplos de mulheres cristãs virtuosas e santas, submissas aos maridos (CLARK, 1983, p. 93; 184; 246). João Crisóstomo, igualmente, deixou um importante relato sobre sua mãe, enaltecendo sua devoção a Deus e subordinação ao marido (CLARK, 1983, p. 202). Nessa perspectiva, São Jerônimo foi indubitavelmente o mais importante dos Padres da Igreja. Além das inúmeras cartas que dedicou às amigas, alunas e benfeitoras, ofereceu-Ihes os Prefácios dos Evangelhos e alguns comentários bíblicos. ${ }^{15}$

Conforme Cain (2009, p. 111), os principais instigadores da expulsão de Jerônimo de Roma foram os membros da família de Paula, por terem sido os mais prejudicados pela liberalidade com que ela dispunha de seu patrimônio. Seja como for, Paula foi "a ovelha modelo" de Jerônimo, segundo Duchesne (apud MARAVAL, 1998, p.47), ${ }^{16}$ acompanhando-o a Belém, onde compartilhou sua vida e herança por mais de trinta anos, construindo com seu dinheiro dois mosteiros, um para mulheres e outro para homens. Das acusações que Ihe foram imputadas diante do um tribunal eclesiástico romano, cujo caráter oficial ainda é incerto (HENNE, 2009, p. 98), Jerônimo soube se defender. Na Carta 45, dedicada à Asela - uma de suas alunas do Círculo do Aventino, escrita pouco antes de sua partida de Roma, provavelmente em julho de 385, Jerônimo relata:

Paene certe triennio cum eis uixi; multa me uirginum crebro turba circumdedit; diuinos libros, ut potui, nonnullis saepe disserui; lectio adsiduitatem, adsiduitas familiaritatem, familiaritas fiduciam fecerat. Dicant quid umquam in me aliter senserint quam Christianum decebat? Pecuniam cuius accepi? Munera uel parua uel magna non spreui? In manu mea aes alicuius insonuit? Obliquus sermo oculus petulans fuit? Nihil mihi aliud obicitur nisi sexus meus, et hoc numquam obicitur, nisi cum Hierosolyma Paula proficiscitur. Esto:crediderunt metienti; cur non credunt neganti? Idem est homo ipse qui fuerat: fatetur insontem qui dudum noxium loquebatur; et certe ueritatem magis exprimunt tormenta quam risus, nisi quod facilius creditur quod aut fictum libenter auditur, aut non fictum ut fingatur inpellitur $(E p ., 45,2)$.

Certamente quase três anos vivi com aquelas <mulheres do Aventino $>.{ }^{17}$ Uma multidão de virgens repetidas vezes me circundou; falei frequentemente para algumas <delas > sobre os livros divinos como pude<da melhor maneira>. 0 ensino havia criado a assiduidade, a assiduidade a familiaridade, a familiaridade a confiança. Elas que digam se perceberam em mim alguma coisa de modo muito diferente do que convinha a um cristão. De quem recebi dinheiro? Não desdenhei os presentes pequenos e grandes? A moeda de outrem tiniu em minha mão? Minha linguagem foi oblíqua, meu olhar imprudente? Nada me é censurado a não ser o meu sexo, e isto nunca se censura, a não ser <agora>, quando Paula está de partida para Jerusalém. Ora vamos, acreditaram no que mente, por que não acreditam no que nega? O homem é aquele mesmo que fora: proclama-se inocente aquele que no passado se dizia culpado. Certamente, as torturas exprimem melhor a verdade do que os risos. A não ser que se creiaou

\footnotetext{
${ }^{15}$ À Paula, Jerônimo dedicou "Efésios", "Filêmon", "Tito", "Gálatas", "Miqueias", "Naum", "Sofonias" e "Ageu", além da tradução do "Comentário sobre Lucas", de Orígenes. À Marcela (e Pamáquio), dedicou o "Comentário sobre Daniel".

${ }^{16}$ Louis Duchesne (1843-1922), prelado e historiador francês.

${ }^{17}$ Colocamos entre os sinais <... palavras que foram acrescentadas na tradução, a fim de torná-la mais clara.
} 
mais facilmente na mentira que se ouve com prazer ou na não mentira que é provocada para que seja maquinada ( $E p ., 45,2$, tradução nossa).

As mulheres cristãs da aristocracia, sem dúvida, foram o principal aporte financeiro para bispos e monges como Jerônimo (SALISBURY, 2001, p. 223). Além do auxílio para a subsistência desses pensadores do catolicismo, as viúvas ricas auxiliavam na construção de igrejas e de mosteiros, faziam doações e davam esmolas para a caridade. Nesse particular, podemos citar Olímpia, que, ao adotar o ascetismo depois de viúva, doou todos os seus bens a João Crisóstomo e à Igreja de Constantinopla, inclusive fundando um mosteiro na cidade (FURLANI, 2012). Melânia patrocinou Rufino em Jerusalém e lá construiu um mosteiro. Paula agiu de modo semelhante ao financiar Jerônimo e ao fundar com ele dois mosteiros em Belém. Não obstante, Jerônimo pede a seu irmão, Pauliniano, numa carta escrita em 397, que ele venda alguns terrenos em sua cidade natal para cobrir despesas em Belém $(E p ., 66,14) .{ }^{18}$ Sabe-se que a construção dos mosteiros durou três anos e que consumiu os recursos de Paula (HENNE, 2009, p. 113).

Ao empregarem suas riquezas em prol da Igreja e de alguns Padres, ao adotarem o ascetismo, essas nobres damas não estavam acumulando somente prejuízos. Na condição de ascetas, tornavam-se noivas de Deus e trilhavam um caminho espiritual que as levaria à perfeição. Sobretudo, o ascetismo proporcionar-lhes-ia liberdade em relação à habitual submissão à figura masculina, seja do pai ou do marido, como nos referimos anteriormente. Na Epístola 130, 8, de 414, escrita à virgem Demétria - da ilustre gens senatorial Anicia, que fugiu para Cartago com sua mãe, depois da invasão dos visigodos a Roma (CAIN, 2009, p.16) -, Jerônimo reforça os benefícios do ascetismo. Segundo ele, a virgindade voluntária ofereceria às mulheres uma liberdade sem precedentes e as libertaria da maldição do Gênesis, ${ }^{19}$ já que não sofreriam as dores do parto e nem seriam dominadas por um homem. Jerônimo vai ainda além, pois, segundo ele, pela via ascética, as mulheres se igualariam aos homens $(E p ., 71,3)$. Exemplo disso é a comparação de Paula com Abraão na Epístola 108, 31.

Quando se lê qualquer um dos escritos de São Jerônimo, exceto a tradução da Bíblia, percebe-se uma enorme intertextualidade, da qual ele faz uso para dar mais peso às ideias que deseja difundir. Esse é um recurso de seu estilo retórico. Para além das obras da literatura clássica greco-latina, bastante empregadas para esse fim, a Bíblia é, sem dúvida, o seu maior interlocutor. Pode-se facilmente extrair de seus escritos as

\footnotetext{
${ }^{18}$ Para um aprofundamento sobre a importância dessas mulheres e de outras aristocratas para a Igreja, vide Clark (1983).

${ }^{19} \mathrm{Gn} 3$, 16: À mulher ele disse: "Multiplicarei as dores de tuas gravidezes, na dor darás à luz filhos. Teu desejo te impelirá ao teu marido e ele te dominará".
} 
bases do ascetismo propagado em Roma, muito bem recebido pelo Círculo do Aventino, frequentado por virgens e viúvas aristocratas. Para Clark (1994, p. 177), a exegese que faz Jerônimo de 1 Coríntios 7, em Aduersus louinianum, bem como de 1 Timóteo 5, na Epístola 123 (ad Geruchiam), lançam aspectos essenciais do ascetismo romano. Na passagem da referida carta aos Coríntios, São Paulo diz que "é melhor para um homem não tocar uma mulher". Essa passagem liga-se aos Provérbios 6, 7 e 9, que advertem os jovens dos perigos a que estão sujeitos os homens quando são tocados pelas mulheres, pois perdem a razão. Partindo dessa afirmação, Jerônimo diz que, se o ato de tocar nas mulheres não é bom para os homens, então necessariamente é mau. Quanto à passagem de Timóteo, Jerônimo a utiliza para se referir à inconveniência para as viúvas de um segundo casamento que seria representado como "as ervas daninhas entre os espinhos". Seja como for, as mulheres que adotaram o ascetismo, fizeram-no de corpo e alma e contribuíram para que São Jerônimo pudesse nos deixar a sua maior herança: a tradução da Bíblia, a Vulgata. Além disso, se não fossem pelas inúmeras cartas dedicadas a essas damas aristocráticas, não saberíamos nada sobre elas e, mais ainda, muitas não teriam sido santificadas, como de fato aconteceu, graças aos escritos de São Jerônimo. Jerônimo, no parágrafo 5 da Epístola 127 (ad Principiam), para sustentar a atitude elogiosa em relação às várias virtudes que teve Marcela em vida, lembra das qualidades das santas mulheres ao pé da cruz do Senhor. Declara que ele, assim como Cristo, julgava a virtude das mulheres não pelo sexo, mas pela alma. Já na Epístola $65,1,{ }^{20}$ também dedicada à Princípia, defendendo-se dos que o criticavam de escrever para mulheres, disse que, se os homens quisessem saber sobre as Sagradas Escrituras, ele não falaria com as mulheres. Em seguida, justifica a importância das mulheres no Antigo e no Novo Testamento, citando o papel que tiveram Débora, Olda, Maria Madalena, Rebeca, Ruth, entre outras. De fato, muitas de suas cartas endereçadas às damas do Aventino são para ensiná-las ou esclarecê-las sobre as Escrituras.

Turcan (1968) vê em São Jerônimo alguém que escolheu como apóstolos as mulheres, com o intuito de que seguissem o caminho do ascetismo.

\footnotetext{
${ }^{20}$ Ep. 65, 1: Scio me, Principia, in Christo filia, a plerisque reprehendi quod interdum scribam ad mulieres, et fragioliorem sexum maribus praeferam. Et idcirco debeo primum obtrectatoribus meis respondere, et sic uenire ad disputatiunculam quam rogasti. Si uiri de scripturis quaererent, mulieribus non loquerer. "Eu sei, Princípia, filha em Cristo, que sou repreendido por muitos porque, algumas vezes, escreveria às mulheres, e que preferiria o sexo frágil aos homens. Por isso, devo primeiro responder aos meus detratores, e na sequência vir a esta questãozinha que perguntaste. Se os homens quisessem saber sobre as Escrituras, não falaria com as mulheres (tradução nossa)".
} 


\section{O Círculo do Aventino}

Antes da chegada de Jerônimo a Roma, Marcela já se reunia em sua mansão, espécie de mosteiro, com sua mãe, Albina, e outras nobres damas da sociedade romana para estudar a Bíblia e praticar a caridade (MORENO, 1992, p. 57). Considerando-se o que diz Jerônimo $(E p ., 127,5)$, Marcela foi uma das primeiras mulheres ascetas em Roma. No parágrafo quinto dessa epístola, que é o seu elogio fúnebre, ele afirma que a decisão de Marcela de seguir o ideal asceta foi por ocasião da presença de sacerdotes de Alexandria em Roma, fato ocorrido em 340. Porém, a adoção da vida ascética e casta de Marcela e a criação do Círculo do Aventino teriam ocorrido por volta do ano de 370 (CAIN, 2009, p. 37).

Marcela (325-410), segundo nos revela Jerônimo (Ep., 127, 1), era de família senatorial, descendente de cônsules e prefeitos do pretório. Logo após ter se tornado viúva, aos sete meses de casamento (Ep., 127, 2), fundou uma espécie de convento em sua casa, junto com sua mãe Albina. Dedicava-se a obras de caridade e ao estudo da Bíblia, com grande interesse em lê-la no original hebraico e no grego da Septuaginta. Nessa mesma epístola (Ep., 127, 5), Jerônimo elogia Marcela por ter sido professora de tão distintas alunas, como Paula e Eustóquia, e, no capítulo 10, credita a ela uma gloriosa vitória contra alguns hereges (Ep., 127, 10). A competência de Marcela era tal que, depois da expulsão de Jerônimo de Roma, ela se tornou professora do Círculo (Ep., 65), fato a que já aludimos anteriormente. Temos testemunho de conselhos dados por Jerônimo sobre o que ela deveria ensinar às noviças $(E p ., 37,4)$, assim como de que dominava muito bem as Escrituras (Ep., 41, 4).

No último capítulo (135) da obra De uiris illustribus, Jerônimo declara que escreveu dezenove cartas à Marcela, sendo que dezesseis estão reunidas num livro cujo nome é Ad Marcellam Epistularum Liber. Dentre as dezenove, três não estão em seu nome ou não foram exclusivamente destinadas a ela (Ep., 46; Ep., 59; Ep., 97). Infelizmente, as cartas enviadas por Marcela (assim como também as que foram enviadas pelas outras participantes do Círculo) não chegaram até nós. Conhecemos o tema dessas dezesseis cartas pelas respostas de Jerônimo a perguntas pontuais de Marcela sobre a interpretação da Bíblia. Por exemplo, na Ep., 25, Jerônimo explica o significado dos dez nomes pelos quais os hebreus designam Deus; na Ep., 26, expõe o significado dos nomes hebraicos Amen e Maran Atha; na Ep., 28, diapsalma, e, na Ep., 29, ephod e teraphim.

Por fim, tal era a amizade entre os dois que, na Ep., 44, Jerônimo agradece os presentes que ela lhe tinha oferecido e aproveita para fazer uma leitura simbólica dos objetos, dizendo que o saco era um símbolo de oração e de jejum, que os assentos 
significavam que as virgens não deviam se dirigir ao exterior, que as velas significavam à espera da chegada do esposo e os cálices a mortificação da carne.

Quanto ao fato de Marcela nunca ter ido a Belém, mesmo tendo sido convidada pelo sacerdote (Ep., 46), Maraval (1998) supõe que uma briga entre os dois teria sido a causa. Para sustentar essa afirmação, o autor aponta a falta de cartas endereçadas a Marcela entre 385 e 394. Entretanto, Cain (2009, p. 69) refuta essa ideia, pois o próprio Jerônimo cita, na Epístola 127, 8, que ele teria estabelecido uma volumosa correspondência com Marcela, após ter deixado Roma. Ademais, o autor lança a hipótese de que Marcela não fora, porque não achava interessante estabelecer residência na Terra Santa. Segundo o autor, mulheres como Paula e Melânia foram exceções (CAIN, 2009, p. 95-96). Outra possibilidade seria de que Marcela não teria aceitado o convite em função da má fama de Jerônimo, depois de ter sido expulso de Roma (CAIN, 2009, p. 97).

Paula (347-404), de família aristocrática, descendente dos Gracos e dos Cipiões, por parte de sua mãe, e de Agamenon, por parte de pai (Ep., 108, 3), ficou viúva aos trinta e dois anos, com quatro filhas e um filho. ${ }^{21} \mathrm{~A}$ partir daí, como asceta, renunciou ao luxo e transformou sua casa num verdadeiro mosteiro, onde todos levavam uma vida de oração e de estudo da Bíblia e praticavam caridade (HENNE, 2009, p. 93). Tal como Marcela, solicitava a Jerônimo muitos esclarecimentos a respeito da Bíblia, principalmente sobre o sentido místico dos textos sagrados. Perguntou-lhe, por exemplo, sobre o sentido simbólico das letras hebraicas presentes no Salmo 118 e, nesse particular, a interpretação de Henne (2009, p.93) é a de que se diferenciava de Marcela, porque esta perguntava mais sobre os aspectos históricos dos textos bíblicos. A resposta de Jerônimo à pergunta de Paula foi dada na $E p$., 30,13, com muitos detalhes, na qual Jerônimo também elogia o seu interesse pelos estudos filológicos. Segundo Turcan (1968, p. 269), Marcela e Paula, pela capacidade intelectual de ambas e pela interação com Jerônimo, certamente devem ter participado no trabalho de tradução da Bíblia.

Quase tudo o que sabemos sobre Paula provém das cartas de Jerônimo, que foram endereçadas a ela ou que falaram sobre ela, principalmente o seu elogio fúnebre (Ep., 108). Esse longuíssimo epitáfio, composto de 34 capítulos, tem sido estudado sob diferentes aspectos, assim como a peregrinação que nele está contida. Lamprecht $(2017$, p. 1) resume que a obra tem sido examinada sob os seguintes aspectos: como hagiografia, homenagem biográfica elogiosa, elogio fúnebre, diário de viagem, livro de memórias, relato metafórico da vida de Paula, peregrinação, e como peça de propaganda ascética, que serviria como uma base textual para o culto de Paula como santa, mártir e asceta em Belém.

\footnotetext{
${ }^{21}$ Toxócio foi o último filho, porque finalmente ela deu à luz a um menino, desejado pelo seu marido $(E p ., 108,4)$.
} 
O capítulo 15 do Epitáfio à Santa Paula é particularmente importante, pois resume as qualidades morais e cristãs de Paula, que a caracterizam como um perfeito modelo de asceta. Nesse capítulo, Jerônimo aproveita para mencionar a retidão de conduta de Paula, depois de ter se tornado viúva. Vale-se igualmente da oportunidade de mostrar que ele se preocupava com o fato de que o patrimônio familiar de Paula estava se desfazendo: "eu desejava ser mais cauteloso sobre a situação do patrimônio familiar, mas ela, com sua fé mais ardente, se apegava com toda sua alma ao Salvador". Assim como Cain (2009, p. 132), interpretamos que Jerônimo estivesse tentando desfazer possíveis suspeitas sobre sua relação com Paula, tanto no plano amoroso quanto material.

Paula parecia ser a contraparte feminina de Jerônimo, não somente pelo ascetismo, mas também pelo amor ao estudo do Evangelho e de línguas. Os trechos abaixo evidenciam essas afirmações:

Seguem abaixo alguns desses aspectos retirados da Epístola 108, 15; 26:

Quae prima Christianorum uirtus est, tanta se humilitate deiecit, ut qui eam uidisset, et pro celebritate nominis uidere gestisset, ipsam esse non crederet, sed ancillarum ultimam. Et cum frequentibus choris uirginum cingeretur, et ueste et uoce et habitu et incessu minima omnium erat. Nunquam post uiri mortem usque ad diem dormitionis suae cum ullo comedit uiro, quamuis eum sanctum et in pontificali sciret culmine positum. Balneas, nisi periclitans, non adiit. Mollia, etiam in grauissima febri, lectuli strata non habuit, sed super durissimam humum stratis ciliciolis quiescebat, si tamen illa quies dicenda est, quae iugibus paene orationibus dies noctesque iungebat, illud inplens de Psalterio: "Lauabo per singulas noctes lectum meum, in lacrimis meis stratum meum rigabo".

Se entre tais e tantas virtudes, ela própria entregou-se à humildade, primeira virtude dos cristãos, é para alguém que a tivesse visto, ou que desejasse ardentemente vê-la pela celebridade do nome, não acreditasse ser ela mesma, mas a última das escravas. E quando se cercava frequentemente de grupos de virgens, dentre todas era a menor delas, não só pela veste, mas pela voz, pelo hábito e pela maneira de andar. Nunca depois da morte do marido até o dia de seu sono eterno, não comeu com nenhum outro homem, ainda que soubesse que fosse santo e provido de um grau elevado no episcopado. Não ia aos banhos a não ser quando estava doente. Igualmente, mesmo quando tinha febres fortíssimas não possuía cama macia, mas deitava-se sobre o chão duríssimo com camadas de pelinhos de cabra, ${ }^{22}$ se, porém, pode-se chamar de repouso os dias e noites que ela unia quase continuamente em orações, cumprindo o Saltério: "lavarei todas as noites o meu leito, e regarei minha cama com as minhas lágrimas".

Loquar et aliud, quod forsitan aemulis uideatur incredulum: Hebraeam linguam, quam ego ab adulescentia multo labore ac sudore ex parte didici, et infatigabili meditatione non desero ne ipse ab ea deserar, discere uoluit, et consecuta est ita ut Psalmos hebraeice caneret, et sermonem absque ulla latinae linguae proprietate resonaret.

\footnotetext{
22 Jerônimo chama a atenção para as vestes das mulheres monásticas, que eram feitas de cilício. O pano de cilício era um tecido grosseiro e resistente, feito a partir de pelos de cabra ou de camelo. No início, era utilizado para armazenar cereais, objetos e alimentos.
} 
Direi o que para alguém que é invejoso talvez pareça inacreditável: a língua hebraica, a qual eu estudei, em parte, desde a adolescência com muito trabalho e suor, e com infatigável contemplação, não a deixo nem sou deixado por ela, <Paula > desejou aprender, e seguiu de tal forma que cantava os Salmos em Hebraico, e ressoava os sermões sem qualquer sotaque de língua latina".

Essa carta, segundo Cain (2010, p. 105), apesar de ter como motivo explícito um consolo à Eustóquia pela morte de sua mãe, na verdade teria sido redigida com o intuito de estabelecer o culto de Paula, já que nela o sacerdote descreve o local de seu enterro e a data de falecimento. No início da Igreja, alguém se tornava santo quando passava a ter um dia estabelecido no calendário litúrgico para que pudesse ser comemorado (CAIN, 2009, p. 134).

Quanto às outras participantes do Círculo, limitar-nos-emos a informações mais sucintas, principalmente pela falta de referências, à exceção das próprias cartas de Jerônimo a elas endereçadas. Neste artigo, de fato, pretendemos ressaltar a importância fundamental de Paula, enquanto mecenas de Jerônimo, e de Marcela, enquanto fundadora do Círculo do Aventino.

Asela (334-385) era irmã de Marcela. Assim como Marcela, jamais foi a Belém para juntar-se a Jerônimo, Paula e Eustóquia. Viveu o ascetismo em uma cela na mansão do Aventino. Graças a um sonho que seu pai tivera durante a sua gestação, foi consagrada desde o nascimento para permanecer virgem e servir a Deus (SALISBURY, 2001, p. 22). Adepta dos jejuns, só comia pão, sal e água (GONZALEZ SALINERO, 2011, p. 549).

Blesila (364-384) era filha de Paula e Toxócio. Casou-se com 18 anos e, assim como Marcella, ficou viúva com sete meses de casamento. Gostava das festas, teatros e dos luxos da vida aristocrática. Em 384 ficou doente, com febres. Após se recuperar, passou a seguir os costumes ascéticos de sua mãe, usando roupas simples e fazendo jejuns. Começou a estudar línguas e as Escrituras, tendo aprendido em tempo recorde grego e hebraico (TURCAN, 1968, p.268). Atribui-se sua morte aos jejuns excessivos incentivados por Jerônimo, já que morreu antes de completar quatro meses de adesão ao novo estilo de vida. A Epístola 39, dedicada à Paula, é o elogio fúnebre de Blesila. Nela, Jerônimo também comenta o fato de o odiarem na cidade e de lhe atribuírem a culpa pela morte de Blesila: "Essa detestável laia de monges, o que estão esperando para expulsá-los da cidade, enterrá-los debaixo de pedras, jogá-los ao mar?" (apud MARAVAL, 1998, p. 53).

Fabíola era uma viúva da gens Fábia. Casou-se duas vezes, tendo se divorciado do primeiro marido e se casado novamente antes de este falecer. Construiu o primeiro hospital civil público em Roma (CAIN, 2009, p. 172; 173; 178). Chegou a ir a Jerusalém na escola de Jerônimo (Ep., 77), mas não permaneceu lá por muito tempo (TURCAN, 1968, p. 266). 
As poucas informações que se tem sobre Léa estão contidas na pequena Epístola 23, composta de três capítulos. Em 23, 1, Jerônimo diz que um pouco depois da hora do terço, foi informado do falecimento de Léa, notícia que o empalideceu. No capítulo 2, descreve suas virtudes de mulher asceta, que depois de viúva renunciou ao luxo e aos bens materiais. Relata que dirigia um mosteiro, ${ }^{23}$ vivia isolada num quarto pequeno, jejuava e passava horas em oração. Tornou-se exemplo de humildade, oração, serviço e testemunho de amor a Cristo. Morreu em Roma, no ano 384.

Eustóquia (c. 368-419), assim como Asela, havia sido dedicada à virgindade perpétua desde seu nascimento (SALISBURY, 2001, p. 118). Participava das reuniões do Círculo e acompanhou sua mãe a Belém, para se unirem a Jerônimo. Após a morte de Paula, em 404, continuou em Belém, comandando os mosteiros fundados por eles. A ela é endereçada a famosa Epístola 22, escrita em 384, na verdade um pequeno tratado composto de 41 capítulos, para incentivá-la a guardar a virgindade, primeira etapa do ascetismo. Jerônimo dá conselhos práticos à Eustóquia, longamente desenvolvidos, apoiando-os em muitas citações bíblicas, dentro do seu estilo belo e habitual. A fim de preservar a virgindade, encoraja a jovem a ter vigilância com os instintos, além de sobriedade, mortificação, recolhimento, leitura, prece, alimentação moderada e contemplação (Ep., 22, 17-18). Não poupa críticas às falsas devotas (Ep., 22, 27) e aos clérigos (Ep., 22, 28), e volta ao tema das chateações do casamento (Ep. 22,2). Como essa epístola não se tratava de uma carta privada, a opinião pública começou a voltar-se contra o sacerdote. Essas críticas iriam se acentuar depois da morte de Blesila, que viera a óbito em novembro de 384, poucos meses após adotar a vida ascética promovida por Jerônimo.

\section{Conclusão}

Este artigo procurou apresentar o Círculo do Aventino, espécie de monaquismo feminino formado por mulheres cristãs - moças virgens ou viúvas - da nobreza romana do século IV. Essas damas da aristocracia empenharam-se em seguir os princípios do cristianismo asceta que, além da abstinência sexual, condição primeira para o início de uma vida de asceta, incluía períodos de jejum, redução do sono, desapego de bens materiais, além do fortalecimento de virtudes morais, como a humildade.

O apoio financeiro de algumas das mulheres nobres do Círculo - notadamente o de Paula - possibilitou não só a construção dos mosteiros feminino e masculino em Belém,

\footnotetext{
${ }^{23}$ Pelo testemunho do próprio Jerônimo nesta ocorrência e também nas $E p$., 22,6 e Ep., 28, percebe-se que houve outros grupos similares aos do Aventino, em Roma. Aliás, de acordo com Cain (2009, p. 94), nas primeiras décadas do século IV, existiu em Roma um grupo de virgens dedicadas à mártir Santa Agnes.
} 
como também o patrocínio de Jerônimo para que ele pudesse realizar a tradução da Bíblia, além de produzir uma obra literária que contribuiu para os fundamentos do catolicismo. Obviamente, Jerônimo não foi o único a alicerçar o cristianismo. Teólogos como Tertuliano, João Crisóstomo, Ambrósio, Joviniano, Agostinho e Pelágio - para citar apenas alguns - são também importantes expoentes da literatura cristã da Antiguidade Tardia.

As ideias de Jerônimo sobre a virgindade, o casamento, a educação das mulheres e a vida perfeita através do ascetismo não foram facilmente aceitas em seu tempo. Temos consciência de que Jerônimo foi um tanto radical e aguerrido em sua postura moral cristã. No entanto, reconhecemos uma particularidade positiva de Jerônimo por valorizar a alma das mulheres e o seu intelecto. Prova disso está na correspondência trocada com as damas do Círculo do Aventino, que o instigaram a refletir sobre as Escrituras e sobre a história e a cultura de sua época. O Círculo do Aventino não foi somente um lugar de estudo sobre as Escrituras e de exegese bíblica, mas, antes, foi um enorme polo de fomento à tradução, ao estudo filológico e à aprendizagem de línguas. Tivemos oportunidade de ver certos exemplos dessas questões em trechos de cartas.

Vale lembrar que algumas mulheres do Círculo foram canonizadas pela Igreja Católica, graças às epístolas de Jerônimo: Marcela (Ep., 127), Paula (Ep., 108), Eustóquia $(E p ., 151)$, Léa (Ep., 23), Asela (Ep., 24), Blesila (Ep., 39) e Fabíola (Ep., 77). Conforme observou Cain (2010, p. 125-126), essas epístolas teriam como objetivo documentar a vida virtuosa dessas mulheres para que, posteriormente, pudessem ser santificadas.

Acreditamos que, se tivessem sobrevivido os escritos das mulheres do Círculo do Aventino, o destino das mulheres no mundo ocidental poderia ter sido diferente, com mais valorização e independência em relação ao mundo masculino.

\section{Referências}

\section{Documentação textual}

BÍBLIA DE JERUSALÉM. São Paulo: Paulus, 2002.

BUTLER, C. The Lausiac History of Palladius. Cambridge: Cambridge University Press, 2014. HIERONYMUS. De Viris Illustribus. Disponível em: https://www.documentacatholicaomnia.eu/02m/03470420,_Hieronymus,_De_Viris_Illustribus_Liber_Ad_Dextrum,_MLT. pdf. Acesso em: 5 nov. 2020.

JEROME, Epistulae 121-154. Corpus Scriptorum Ecclesiasticorum Latinorum 56. Disponível em: https://archive.org/details/CSEL56/page/n4/mode/1up?view=theater. Acesso em: 01 jul. 2021. 
JEROME, Epistulae 71-120. Corpus Scriptorum Ecclesiasticorum Latinorum 55. Disponível em: https://archive.org/details/corpusscriptorum55stuoft/page/n3/mode/1up?view=theater. Acesso em 01/07/2021.

JEROME, Epistulae1-70. Corpus Scriptorum Ecclesiasticorum Latinorum 54. Disponível em: https://archive.org/details/corpusscriptorum54stuoft/page/n7/mode/1up?view=theater. Acesso em: 01 jul. 2021.

\section{Obras de referência}

BLAISE, A. Dictionnaire latin-français des auteurs chrétiens. Turnhout: Brepols, 1954.

HAMMOND, N. G. L.; SCULLARD, H. H. The Oxford classical dictionary. Oxford: Clarendon Press, 1970.

SALISBURY, J. Encyclopedia of women in the Ancient World. Santa Barbara: ABC CLIO, 2001.

\section{Obras de apoio}

ARNS, P. A técnica do livro segundo São Jerônimo. São Paulo: Cosac Naify, 2007.

BERNARD, E. Les voyages de Saint Jérôme. Thèse présentée à La Faculté de Paris, 1864.

Disponível em: https://gallica.bnf.fr/ark:/12148/bpt6k73209s?rk=21459;2. Acesso em: 20 jun. 2021.

CAIN, A. Jerome's 'Epitaphium Paulae': hagiography, pilgrimage, and the cult of Saint Paula. Journal of Early Christian Studies, n. 18(1), p. 105-139, 2010.

CAIN, A. The letters of Jerome: asceticism, biblical exegesis, and the construction of Christian authority in Late Antiquity. Oxford: Oxford University Press, 2009.

CAIN, A. 'Vox clamantis' in deserto. Journal of Theological Studies, n. 57 (2), p. 500-525, 2006.

CLARK, E. Reading renunciation: asceticism and Scripture in Early Christianity. Princeton: Princeton University Press, 1999.

CLARK, E. Women in the Early Church. Wilmington: Michel Glazier, 1983.

CLARK. E. Ideology, history, and the construction of "woman" in the Late Ancient Christianity. Journal of Early Christian Studies, v. 2, n. 2, p. 155-184, 1994.

FURLANI, J. C. Igreja, ascetismo e poder na Antiguidade tardia: o diaconato de Olímpia em Constantinopla. Plêthos, n. 2, v. 1, 2012, p. 151-164.

GONZALEZ SALINERO, R. Ocio y ascesis aristocrática: Jerónimo y sulectio divina en Roma (382-385). Espacio, Tiempo y Forma, t. 24, p. 543-562, 2011.

HENNE, Ph. Saint Jérôme. Paris: Cerf, 2009. 
KELLY, J. N. D. Jerome: his life, writings, and controversies, London: Duckworth, 1975.

LAMPRECHT, J. Jerome's letter 108 to Eustochium: contemporary biography in service of ascetic ideology? Teologiese Studies, n. 73, p. 1-10, 2017.

MACHADO, C. A Antiguidade Tardia, a queda do Império Romano e o debate sobre o "fim do mundo antigo". Revista de História, n. 173, p. 81-114, 2015.

MARAVAL, P. Jerônimo: tradutor da Bíblia. São Paulo: Paulinas, 1998.

MARAVAL, P. Lieux saints et pèlerinages d'Orient: histoire et géographie des origines à la conquête arabe. Paris: Du Cerf, 2004.

MARAVAL, P. Récits des premiers pèlerins chrétiens au Proche-Orient (IVème - VIIème siècle). Paris: Du Cerf, 2002.

MARCOS SANCHEZ, M. La visión de la mujer en San Jeronimo a traves de su correspondecia. In: GARRIDO GONZÁLEZ, E. (ed.). La mujer nel Mundo Antiguo: Actas de Las V Jornadas de Investigacion Interdisciplinaria. Madrid: Ediciones de la Universidad Autónoma de Madrid, 1986.

MARTINS, M. C. A peregrinação de Jerônimo e Paula. Translatio, n. 20, p. 198-230, 2020.

MARTINS, M. C. Peregrinação de Egéria: uma narrativa de viagem aos Lugares Santos. Uberlândia: EDUFU, 2017.

MORENO, F. São Jerônimo: a espiritualidade do deserto. São Paulo: Loyola, 1992.

RICE, E. Saint Jerome in the Renaissance. Baltimore: Johns Hopkins University Press, 1985

TURCAN, M. Saint Jérôme et les femmes. Bulletin de l'Association Guillaume Budé, n. 2-3, p. 259-272, 1968. 